UDC 621.039 .548

621.039 .586

\title{
RESEARCH THE BEHAVIOUR AND PROPERTIES OF WWER TYPE FUEL CLADDINGS FROM Zr1\% Nb ALLOY IN LOSS OF THE COOLANT ACCIDENT
}

\author{
M.M. Semerak, S.S. Lys \\ Lviv Polytechnic National University, Lviv, Ukraine \\ E-mail: lysss@ukr.net
}

The paper presents safety criteria placed on fuel rod condition in loss of the coolant accident (LOCA) conditions as applied to reactor plants with WWER. The paper reveals briefly experimental studies carried out to validate safety criteria (acceptance criteria). The scope of the data experimentally obtained by research the behaviour and properties of WWER type fuel claddings from $\mathrm{Zr} 1 \% \mathrm{Nb}$ alloy under loading conditions simulating the stage of core flooding with water in LOCA suffices to judge the character and numerical value of criterional parameters of the embrittlement criterion in terms of the cladding stability upon flooding and subsequent implementation of fuel assembly (FA) unloading and transportation. Accidents are considered involving loss of coolant by primary circuit which are characterized by conditions of degraded heat transfer from fuels. During accidents loss of tightness by fuel rod cladding is tolerable, however, in this case, the cooling of a distorted fuel rod and the dismantling (unloading) of the core after an accident have to be feasible.

\section{INTRODUCTION}

Validation of reactor plant (RP) safety under accident conditions is an indispensable component of work to license NPP operation. The most important element of RP safety validation is analysis of behaviour of nuclear fuel (FS, fuel rods) in design basis (postulated) accidents.

The objective of the work is research the behaviour and properties of WWER type fuel claddings from $\mathrm{Zr} 1 \% \mathrm{Nb}$ alloy under loading conditions simulating the stage of core flooding with water in LOCA. A design basis accident is the one for which the design defines initial events and final states as well as contemplates safety systems that with the account for a single failure of safety systems or a single staff error, independent of an initial event, provide for the limitation of its consequences via limits established for accidents of this type $[1,2]$.

Accidents are considered involving loss of coolant by primary circuit which are characterized by conditions of degraded heat transfer from fuels. Under these conditions, the temperature of fuel rods (fuel and/or cladding) rises compared to that under normal operating conditions. During accidents loss of tightness by fuel rod cladding is tolerable, however, in this case, the cooling of a distorted fuel rod and the dismantling (unloading) of the core after an accident have to be feasible.

These requirements are provided via introducing some limitations on the parameters of the major processes proceeding in a fuel rod in design basis accidents, namely:

- embrittlement of fuel rod cladding (decreased ductility) effected by its intensive oxidation at elevated temperatures that can lead to a fuel rod destruction into several fragments (fragmentation) at the stage of core cooling down;

- hydrogen release that may lead to a hydrogen explosion in the core and is also related to intensive oxidation;

- fuel melting.

\section{FORMULATION OF THE PROBLEM}

The major requirements for the RP safety are called upon to provide the permanent cooling and the feasibility of a core discharge $[1,2]$.

In LOCA these requirements are met when the maximal design limit of fuel rod damage is not exceeded [2]. The fuel rods safety state in LOCA is stipulated by the following acceptance criteria:

\footnotetext{
Maximal design limit
of fuel
rod damage

$>$
$>$
$>$ Maximum temperature of cladding does not exceed $1200{ }^{\circ} \mathrm{C}$

$>$ Maximum local depth of cladding oxidation is not higher than $18 \%$ of its original thickness

Fraction of steam reacted $\mathrm{Zr}$ in core is not higher than $1 \%$ of its mass in fuel cladding

$>$ Fuel temperature does not exceed fuel melting temperature
}

\author{
$\diamond \quad$ Limitation of \\ embrittlement
Limitation of hydrogen
$\diamond$ release \\ Absence of melted \\ $\diamond \quad$ fuel-cladding \\ interaction
}


The validation and check-up of safety criteria are performed via:

- experimentally implemented validation of safety criteria;

- design analysis of fuel rod state in design basis accidents at the detailed design stage;

- check-up of fulfilling (not exceeding) safety criteria.

\section{ANALYSIS OF CRITERION LIMITING EMBRITTLEMENT OF $\mathrm{Zr1 \%}$ Nb FUEL CLADDING MATERIAL}

In process of LOCA, the inadequate cooling of fuel claddings gives rise to their heating to reach high temperatures. Under these conditions, their intensive steam oxidation is feasible.

The degree of the cladding oxidation is basically governed by the levels of temperatures and pressure, time of oxidation in steam and deformation.

As a results of the cladding-steam interaction, the cladding material becomes brittle.

Because of the cladding material embrittlement, the $\mathrm{Zr} 1 \% \mathrm{Nb}$ alloy changes its original thermophysical and mechanical properties, and the ductility characteristics become lower. The thickness of the unoxidized cladding material is reduced.

Temperature stresses of cladding arising at the stage of core flooding with water from the emergency cooling system as well as mechanical loads effected by fuel assembly (FA) unloading and transportation may lead to the fragmentation of an embrittled cladding.

The degree of $\mathrm{Zr} 1 \% \mathrm{Nb}$ cladding-coolant interaction is stipulated by the maximum limit of a fuel rod damage in terms of the tolerable depth of cladding oxidation, namely, the embrittlement criterion [1].

The degree of the $\mathrm{Zr} 1 \% \mathrm{Nb}$ cladding embrittlement is limited by two criterional parameters $T_{\text {clad }}^{\text {lim }}$ and local oxidation depth of cladding (equivalent cladding reacted - ECR) ECR $_{\text {clad }}^{\lim }$ :

- the maximal cladding temperature $\mathrm{T}_{\text {clad }}$ does not exceed $1200{ }^{\circ} \mathrm{C}$

$$
T_{\text {clad }}<T_{\text {clad }}^{\lim }=1200{ }^{\circ} \mathrm{C} \text {. }
$$

The ultimate value of the fuel cladding temperature $T_{\text {clad }}^{\lim }$ characterizes the temperature with the exceeding of which a self-sustaining $\mathrm{Zr}$-steam reaction may begin.

- the maximum ECR is not more than $18 \%$ of its original thickness $\mathrm{ECR}_{\text {clad }}^{\lim }$

$$
\mathrm{ECR}<\mathrm{ECR}_{\text {clad }}^{\lim }=18 \% .
$$

The ultimate magnitude of ECR reflects the degree of the embrittlement of a fuel cladding material and, if it is exceeded, a cladding may fracture in brittle mode as a result of loads produced by the emergency core cooling, discharge, handling and transportation of FA.

ECR is an overall thickness of an equivalent $\mathrm{Zr}$ layer (that would react with steam assuming the whole locally absorbed oxygen would be spent to form stoichiometric $\mathrm{Zr}, \mathrm{ZrO}_{2}$ ) related to the original cladding thickness.
If a fuel rod is ruptured (depressurized), the oxidation of both outer and inner surfaces of cladding are taken into account.

The degree of oxidation as applied to $\mathrm{Zr} 1 \% \mathrm{Nb}$ claddings is assessed from either the oxygen specific weight gain, $\Delta \mathrm{m}$, or ECR. [4]

ECR and weight gain, $\Delta \mathrm{m}$, are related by the ratio

$$
\mathrm{ECR}=N \cdot\left(\delta_{\mathrm{e}} / \delta_{\mathrm{o}}\right) \cdot 100 \%,
$$

wehre $N$ - is the coefficient that takes into account the oxidation of cladding at both the surfaces $(N=2$ for a ruptured); $\delta_{o}-$ is original thickness of specimen, $\mathrm{cm}$; $\delta_{\mathrm{e}}-$ is thickness of equivalent layer (calculated thickness of $\mathrm{Zr}$ layer that would be spent to form $\mathrm{ZrO}_{2}$ ), $\mathrm{cm}$;

$$
\delta_{\mathrm{e}}=\mu_{\mathrm{Zr}} / \mu_{\mathrm{O}_{2}} \cdot 1 / \rho_{\mathrm{Zr}} \cdot \Delta m
$$

$\mu_{\mathrm{Zr}}, \mu_{\mathrm{O}_{2}}-$ are molecular masses of zirconium and oxygen, respectively; $\rho_{\mathrm{Zr}}-$ is zirconium density, $\mathrm{mg} / \mathrm{cm}^{3} ; \Delta \mathrm{m}-$ is specific weight gain, $\mathrm{mg} / \mathrm{cm}^{2} ; \Delta m=\Delta M / S_{\mathrm{o}} ; \Delta M-$ is oxygen weight gain, $\mathrm{mg} ; S_{\mathrm{o}}$ - is area of original cladding surface, $\mathrm{cm}^{2}$.

It is to be pointed out that the specific weight gain of a cladding is found by dividing the weight gain by the area of the original cladding surface. This gives a conservative assessment of the specific weight gain. The real oxidized area may be larger at the expense of possible cladding deformation [4].

The ration to determine ECR has the form of

$$
\mathrm{ECR}=N \times 4.355 \cdot 10^{-2} \cdot \Delta m / \delta_{\mathrm{o}} \% .
$$

It is recommended to determine the oxygen weight gain of $\mathrm{Zr} 1 \% \mathrm{Nb}$ claddings via the parabolic ratio [5]

$$
\Delta m=920 \cdot \exp (-10410 / T) \cdot \sqrt{\tau},
$$

where $\Delta m$ - is specific weight gain, $\mathrm{mg} / \mathrm{cm}^{2} ; T-$ is temperature, $\mathrm{K} ; \tau-$ is time, $\mathrm{s}$.

The relation (2) recommended for the assessment the degree of $\mathrm{Zr} 1 \% \mathrm{Nb}$ cladding oxidation is conservative at the temperatures of $900 \ldots 1200{ }^{\circ} \mathrm{C}$ and the time of the alloy-steam interaction up to $900 \mathrm{~s}$ for the case of the availability of a hydrogen additive in steam, deformation of cladding and irradiation.

\section{RESULTS ON EXPERIMENTALLY VALIDATED EMBRITTLEMENT CRITERION}

The embrittlement criterion pertaining to $\mathrm{Zr} 1 \% \mathrm{Nb}$ fuel claddings is validated by the results of the following experiments [3-7]:

- research of fuel cladding ability to withstand quenching (thermal shock tests);

- estimation of the physico-mechanical state of oxidized specimens after flooding with cool water or after quick removing into cool water (estimation of impact elasticity and residual ductility), metallographic examinations of oxidized specimens subjected to a thermal shock.

\section{Thermal shock tests}

Requirements for the procedure used to test for thermal shock (Table 1) comprise the following:

- indirect heating of specimens in well thermostatically-controlled facility; 
- isothermal exposure; time and temperature being recorded;

- quick removing of a specimen into cool water (or the flooding of a specimen from bottom);
- analysis of a tested simulator state;

- formation of simulator failure map.

The parameters of the thermal shock tests

\begin{tabular}{|c|c|c|c|}
\hline \multirow{2}{*}{ Parameters } & \multicolumn{3}{|c|}{ Facility } \\
\hline & UNOPRO & TEFSAI & UVS \\
\hline Simulator cladding temperature, ${ }^{\circ} \mathrm{C}$ & $900 \ldots 1200$ & $900 \ldots 1300$ & $1000 \ldots 1200$ \\
\hline Simulator heating rate, deg/s & var & $10 \ldots 20$ & $\begin{array}{c}1 \ldots 3 \\
\left.\text { (from } 800^{\circ} \mathrm{C}\right)\end{array}$ \\
\hline Steam pressure, MPa & 0.1 & 0.1 & 0.1 \\
\hline Steam specific transfer, $\mathrm{mg} / \mathrm{cm}^{2} / \mathrm{s}$ & 7 & 50 & $2 \mathrm{~g} / \mathrm{min}$ \\
\hline Flow rate of carrier gas (argon), $\mathrm{cm}^{3} / \mathrm{min}$ & - & - & $140 \pm 6$ \\
\hline Temperature of flooded water (immersion), ${ }^{\circ} \mathrm{C}$ & 20 & 20 & $25 \ldots 35$ \\
\hline $\begin{array}{l}\text { Rate of flooding from bottom, } \mathrm{m} / \mathrm{s} \\
\text { (immersion), } \mathrm{s}\end{array}$ & 0.2 & 0.2 & $0.5 \ldots 0.8$ \\
\hline Cooling rate, $\mathrm{deg} / \mathrm{s}$ & $\sim 100$ & $\sim 100$ & $\sim \sim 100$ \\
\hline
\end{tabular}

In the experiments carried out with short-length simulators (Table 2), account was taken of many loading factors involved in LOCA. The use of a shortlength simulator ensured a uniform in height and time controlled temperature field. The availability of $\mathrm{UO}_{2}$ pellets (or sintered $\mathrm{Al}_{2} \mathrm{O}_{3}$ ) gave essentially real values of temperature effected stresses arising in a cladding upon flooding (quick immersion) with cool water. The tests were implemented using both integer fuel rod simulators internally pressurized with an inert gas (deformation of cladding was simulated) and those having unsealed ends (not pressurized).

Table 2

Components of types $1-4$ simulators

\begin{tabular}{|c|c|c|c|c|}
\hline \multirow{2}{*}{\multicolumn{2}{|c|}{ Component }} & \multicolumn{3}{|c|}{ Facility } \\
\hline & & INOPRO & TEESA & JVYC \\
\hline \multirow[t]{2}{*}{ Cladding } & Material & $\mathrm{Zr} 1 \% \mathrm{Nb}$ & $\mathrm{Zr} 1 \% \mathrm{Nb}$ & $\mathrm{Zr} 1 \% \mathrm{Nb}$ \\
\hline & Length & $60 \mathrm{~mm}$ & $120 \mathrm{~mm}$ & $60 \mathrm{~mm}$ \\
\hline \multirow[t]{2}{*}{ Pellet } & Material & $\mathrm{Al}_{2} \mathrm{O}_{3}$ & $\mathrm{UO}_{2}$ & $\mathrm{UO}_{2}$ \\
\hline & Shape & \multicolumn{3}{|c|}{ Standard - WWER type } \\
\hline Plug & Material & $\mathrm{Zr} 1 \% \mathrm{Nb}$ & - & $\mathrm{Zr} 1 \% \mathrm{Nb}$ \\
\hline
\end{tabular}

The experiments with unirradiated claddings were carried out in two facilities:

- with specimen heating in a shaft-type furnace; the weight gain of a specimen being continuously recorded during of the experiment - UNOPRO;

- with heating simulator cladding placed in the central hole of $\mathrm{UO}_{2}$ pellets - TEFSAI.

The experiments with irradiated claddings were carried out in all-purpose rigs UVS [3].

The experiments to study the thermal resistance were carried out in a wide temperature range
$900 \ldots 1200^{\circ} \mathrm{C}$; the cladding oxidation degree was different (from 18 to $60 \% \mathrm{ECR}$ ).

The data were acquired on the heat resistance of WWER type fuel claddings operated to reach the burnup of $\sim 50$ (MW day) $/ \mathrm{kg} \mathrm{U}$.

Simulators having unirradiated (types 1-3) and irradiated (type 4) claddings used in tests for heat resistance are schematically depicted in Fig. 1.

The results of the thermal shock tests are presented as maps illustrating the ability of $\mathrm{Zr} 1 \% \mathrm{Nb}$ claddings to resist thermal shock - failure maps. The results of the thermal shock tests are plotted on the failure map as temperature of oxidation vs oxidation time.

Table 3

The boundaries of the allowable ranges of cladding state

\begin{tabular}{|c|c|}
\hline Maximally allowable temperature $T_{\text {clad }}^{\lim }=1200{ }^{\circ} \mathrm{C}$ & Vertical straight line \\
\hline Maximally allowable degree of oxidation $\mathrm{ECR}_{\text {clad }}^{\lim }=18 \%$ & Inclined straight line \\
$(\Delta \mathrm{m}$ is calculated from ratio (2) $)$ & \\
\hline
\end{tabular}

The results of the tests for thermal shock evidence that the claddings of the types 1-4 simulators fractured outside the range of the allowable cladding state (Figs. 2-5).
The embrittlement criterion " $1200{ }^{\circ} \mathrm{C}-18 \%$ ECR" (Table 3) for $\mathrm{Zr} 1 \% \mathrm{Nb}$ claddings of WWER type fuel rods was corroborated experimentally. 
Type 1
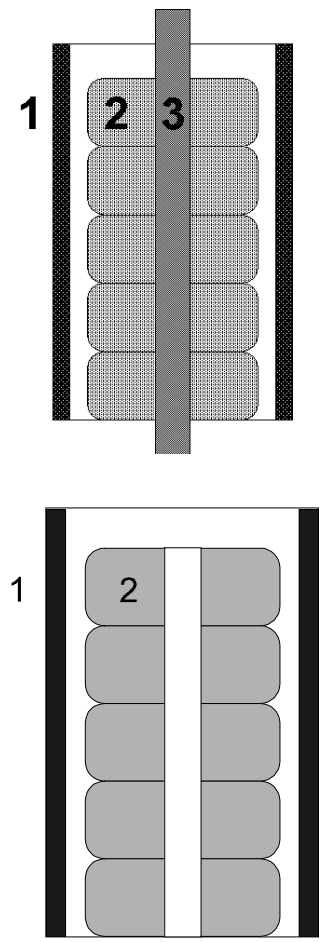

Type 2

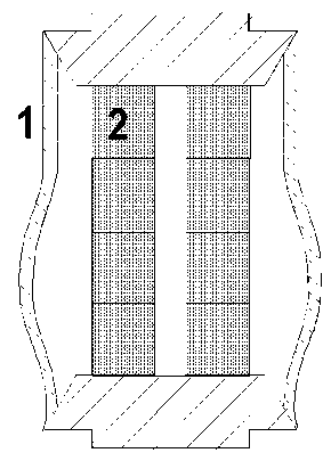

Type 4

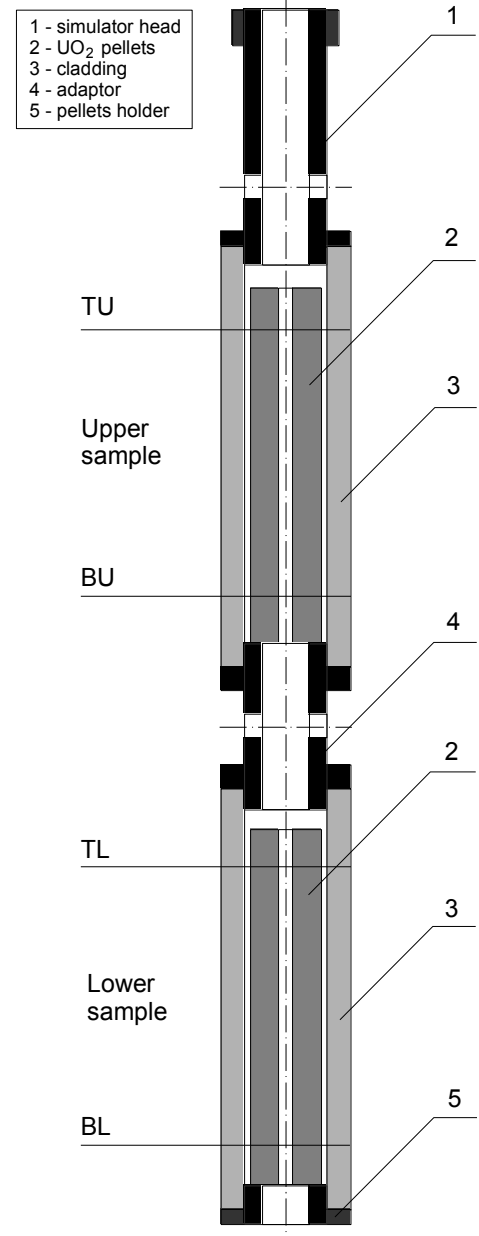

Type 3 (simulation of cladding deformation)

Fig. 1. Schemes of simulators: 1 -cladding; 2 -pellet $\left(\mathrm{AL}_{2} \mathrm{O}_{3}\right.$-types 1, 3; UO $\mathrm{O}_{2}$-type 2); 3 -tungsten heater

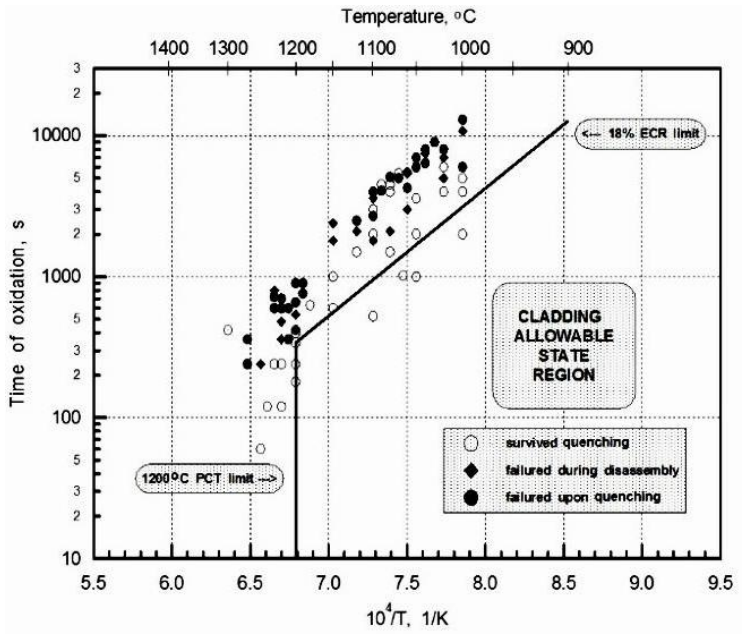

Fig. 2. Cladding failure map. Simulator of type 1

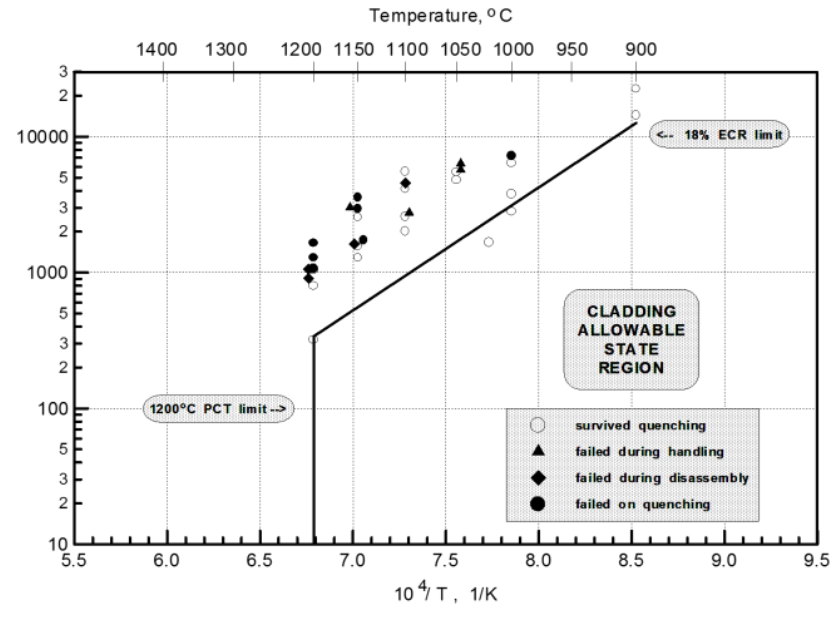

Fig. 3. Cladding failure map. Simulator of type 2 


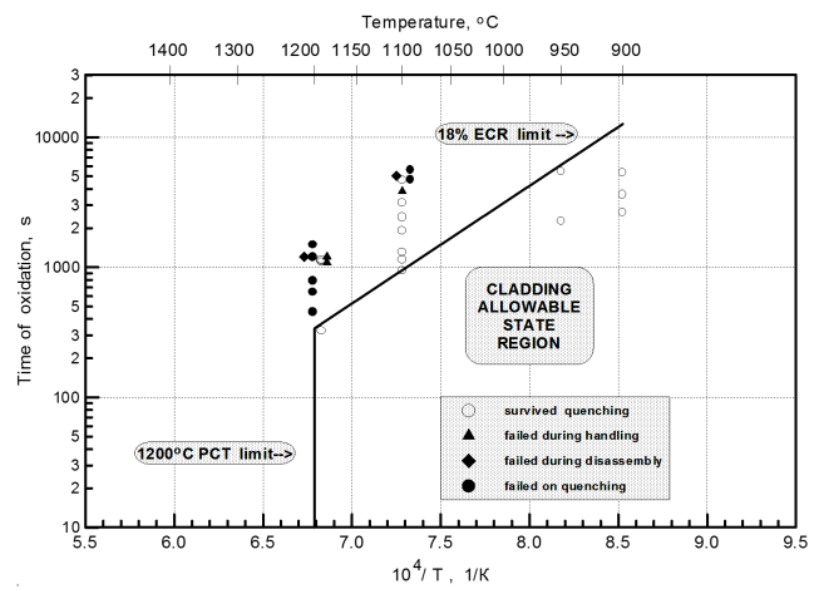

Fig. 4. Cladding failure map. Simulator of type 3

\section{ESTIMATION OF MECHANICAL PROPERTIES OF OXIDIZED CLADDINGS SUBJECTED TO THERMAL SHOCK}

The mechanical properties of oxidized claddings of cold water quenched fuel rod simulators were estimated from the results of impact testing (estimation of impact elasticity) and compression testing in the direction normal to the specimen symmetry axis (estimation of residual ductility).

\section{Compression tests}

To assess the mechanical properties of oxidized $\mathrm{Zr} 1 \% \mathrm{Nb}$ claddings subjected to a thermal shock, use was made of the results of compression testing 30 or $50 \mathrm{~mm}$ long pieces cut off from pre-oxidized WWER tubes $(\varnothing 9.15 \times 7.72 \mathrm{~mm})$. The compression tests were carried out at room and elevated temperatures in the Instron-TT-DM machine and in a high temperature vacuum facility $1246 \mathrm{P}-2 / 2300$, respectively. The grip displacement rate is $2 \mathrm{~mm} / \mathrm{min}$. The strain temperature is $20 \ldots 900^{\circ} \mathrm{C}$.

The results of the compression tests revealed a clearcut distinction between the specimens having a ductility margin (complete ductility, low ductility) and those that fractured in a brittle mode (Fig. 6).

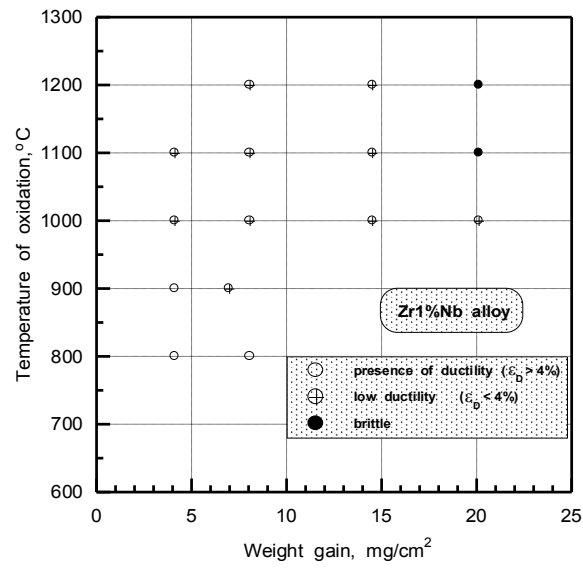

Fig. 6. Compression tests $\left(T_{\text {test }}=20^{\circ} \mathrm{C}\right)$

A strong dependence of the "ductility boundary" on a testing temperature and a specimen weight gain can be seen [7].

The results of the compression testing showed that the ductility characteristics of $\mathrm{Zr} 1 \% \mathrm{Nb}$ and $\mathrm{Zry}-4$ alloys

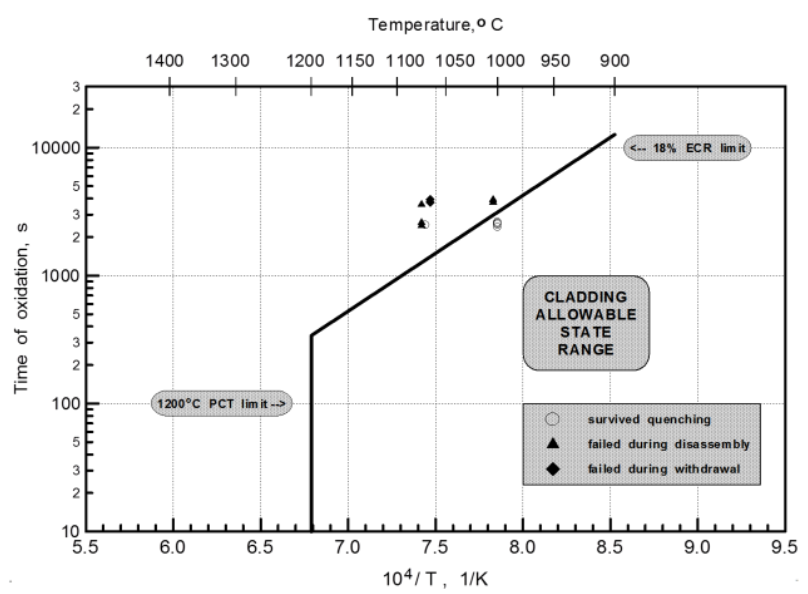

Fig. 5. Cladding failure map. Simulator of type 4

differed at a room temperature [8]. This difference reduces with the rise of the compression testing temperature.

\section{Impact tests}

In our view, the estimation of the oxidized $\mathrm{Zr} 1 \% \mathrm{Nb}$ cladding elasticity from the results of impact tests is most unbiassed.

In the experiments assessing the impact elasticity of cold water quenched oxidized claddings, original specimens were used; they were prepared from claddings of fuel rod type 2 simulators that remained integer after testing for thermal shock.

A notch $0.5 \mathrm{~mm}$ wide and $1.0 \ldots 1.5 \mathrm{~mm}$ deep was cut in a simulator cladding $100 \mathrm{~mm}$ long using a diamond disc. The impact elasticity tests were carried out using a pendulum hammer of the PSV -1.5 type:

Testing temperature..................20 ${ }^{\circ} \mathrm{C}$;

Maximum impact energy............. $15 \mathrm{~J}$;

Impact speed....................... $3 . .4 \mathrm{~m} / \mathrm{s}$.

The impact strength was calculated via the formula $a_{\mathrm{k}}=W / F$,

where $W-$ is fracture strength, $\mathrm{J} ; F-$ is a specimen cross area at a point of shock load application, $\mathrm{cm}^{2}$.

The impact elasticity of $\mathrm{Zr} 1 \% \mathrm{Nb}$ specimens in the original state equals $64.2 \ldots 89.3 \mathrm{~J} / \mathrm{cm}^{2}$. This value is a factor of $\sim 2$ higher than that of Zry-4F specimens.

The tough fracture mode shown by $\mathrm{Zr} 1 \% \mathrm{Nb}$ claddings oxidized at $900 \ldots 1300{ }^{\circ} \mathrm{C}$ takes place upon oxidation to $5 \%$ ECR in impact tests (Fig. 7).

At a higher oxidation degree, claddings fracture in a mixed mode while at the oxidation degree more than $7 \% \mathrm{ECR}$, the fracture of claddings is brittle.

As far as Zry-4F claddings, the critical oxidation degree at the tough to brittle fracture transition is not less than 7\% ECR. The same procedure was used to test the specimens of both the alloys.

According to [9], the critical impact elasticity of Zry-4 claddings was $1.25 \mathrm{~J} / \mathrm{cm}^{2}$. If this value is normalized to the cross section area of the transformed $\beta$-Zry it will be $\sim 1 \mathrm{~J} / \mathrm{cm}^{2}$. Fig. 8 indicates the impact elasticity range within which $\mathrm{Zr} 1 \% \mathrm{Nb}$ cladding does not fracture when cold quenched (subjected to thermal shock). At the degree of $\mathrm{Zr} 1 \% \mathrm{Nb}$ cladding oxidation to $18 \%$ ECR, the impact strength remains not lower than $1 \mathrm{~J} / \mathrm{cm}^{2}$. 


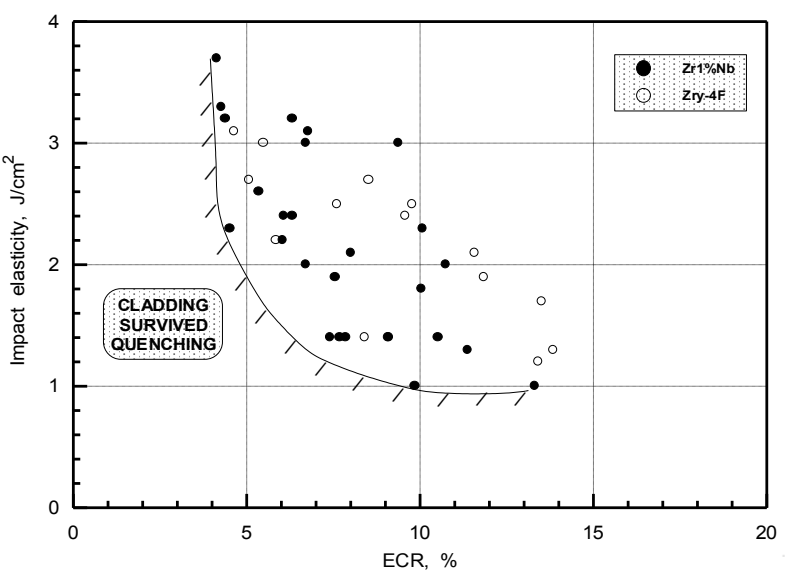

Fig. 7. Impact elasticity of oxidized claddings vs oxidation degree

Metallographic examinations

Examinations of the cladding microstructure allowed determination of the thickness of $\mathrm{Zr} 1 \% \mathrm{Nb}$ - steam interaction layers $\left(\mathrm{ZrO}_{2}, \alpha-\mathrm{Zr}(\mathrm{O}), \beta-\mathrm{Zr}\right)$ formed as a result of the oxidation. The estimation of the degree of the cladding oxidation based on the results of the metallographic measurements of interaction layer thicknesses is an indirect one.

The knowledge of the oxygen distribution within the interaction layer thickness gives an idea of the influence produced by absorbed oxygen on the ductile (plastic) properties of claddings. The indirect estimation of the oxygen content and distribution within interaction layers was carried out based on the results of measuring the microhardness of layers.

The microhardness of claddings was measured with PMT-3 microhardness tester at the load of $50 \mathrm{~g}$. The error of the measurements was $\pm 8 \mathrm{~kg} / \mathrm{mm}^{2}$.

Metallographic examinations revealed that the (metal $+\alpha-\operatorname{Zr}(\mathrm{O})$ ) layer thickness averaged hardness $\mathrm{H}_{50}$ of the claddings of types 1-4 simulators oxidized at temperatures $<1050{ }^{\circ} \mathrm{C}$ to $43 \%$ ECR amounts up to $600 \mathrm{~kg} / \mathrm{mm}^{2}$ at the cladding thickness up to two times reduced compared to the original thickness (Fig. 8).

The microhardness of the metal part of the $\mathrm{Zr} 1 \% \mathrm{Nb}$ claddings oxidized at $<1050{ }^{\circ} \mathrm{C}$ increases with the oxidation degree.

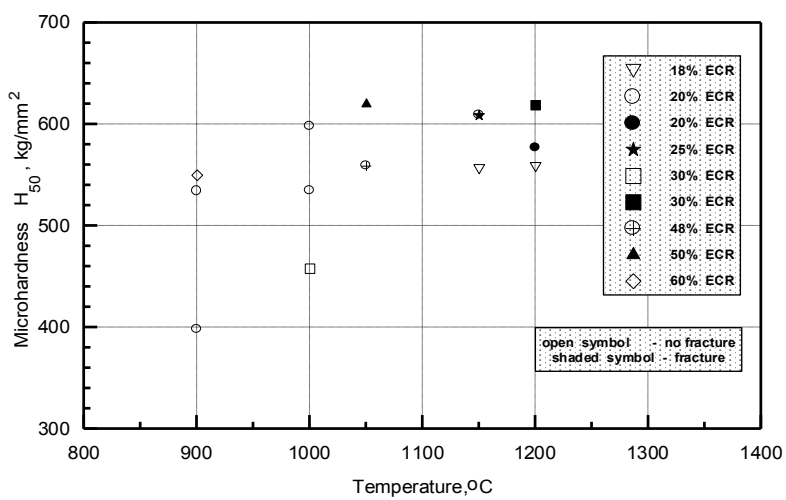

Fig. 8. Variation in (metal $+\alpha-\operatorname{Zr}(O))$ layer thickness averaged microhardness of $\mathrm{Zr} 1 \% \mathrm{Nb}$ claddings vs oxidation temperature
The microhardness of claddings oxidized at $1100 \ldots 1200{ }^{\circ} \mathrm{C}$ is weakly dependent upon the oxidation degree (see Fig. 8).

It is to be noted that as far as $\mathrm{Zr} 1 \% \mathrm{Nb}$ alloy, the rate of the $\alpha$-phase microhardness increase is higher compared to Zry-4 (particularly, at the early stages of oxidation). This difference may result from different ultimate solubilities of oxygen in the $\beta$-phase of the two alloys at identical temperatures of their oxidation.

\section{CONCLUSIONS}

The analysis of the data experimentally obtained by research the behaviour and properties of WWER type fuel claddings from $\mathrm{Zr} 1 \% \mathrm{Nb}$ alloy under loading conditions simulating the stage of core flooding with water in LOCA suffices to shows the character and numerical value of criterional parameters of the embrittlement criterion in terms of the cladding stability upon flooding and subsequent implementation of FA unloading and transportation.

The representative maximal design limit of fuel rod damage in terms of oxidation (embrittlement criterion) comprises all together the maximum temperature of the fuel cladding heating and the local depth of cladding oxidation.

The numerical values of the criterional parameters $T_{\text {clad }}^{\lim }=1200{ }^{\circ} \mathrm{C}$ and $\mathrm{ECR}_{\text {clad }}^{\lim }=18 \%$ are validated by the experimental data obtained from studies into the kinetics of the $\mathrm{Zr}$-steam reaction and from the specially implemented thermal shock experiments.

It is demonstrated that the mechanical properties of oxidized claddings upon a thermal shock (impact elasticity, residual ductility) are adequate for claddings to be stable upon flooding and subsequent handling FA (unloading and transportation).

\section{REFERENCES}

1. Obshchiye polozheniya obespecheniya bezopasnosti atomnykh stantsiy OPB-88/97. NP-001-97 (PNAE G-01-011-97): Utverzhdeny postanovleniyem Gosatomnadzora Rossii №9 ot 14.11.97 (in Russian).

2. Pravila yadernoy bezopasnosti reaktornykh ustanovok atomnykh stantsiy. PBYA PU AS-89. Vvedeny v deystviye s 01.09.90 (in Russian).

3. Yu.K. Bibilashvili, N.B. Sokolov, L.N. AndreevaAndrievskaya, V.Yu. Tonkov, A.V. Salatov, A.M. Morosov, V.P. Smirnov. The oxydized Zr1\%Nb WWERtype fuel rod claddings heat resistance during quenching in loss of the coolant accident conditions $/ / 6^{\text {th }}$ International QUENCH Workshop, Forschungszentrum Karlsruhe, October 10-12, 2000.

4. Yu.K. Bibilashvili, N.B. Sokolov, V.V. Dranenko, et al. Vliyaniye vysokotemperaturnogo okisleniya $i$ teplovykh udarov na deformatsiyu do razrusheniya obolochek tvelov iz splavov na osnove tsirkoniya // Voprosy atomnoy nauki $i$ tekhniki. Seriya "Materialovedeniye i novyye materialy". 1991, N 2(42), p. 34-39 (in Russian).

5. Yu.K. Bibilashvily, N.B. Sokolov, L.N. Andreyeva-Andrievskaya, A.V. Salatov, A.M. Morozov. Hightemperature Interaction of Fuel Rod Cladding Material (Zr1\% Nb alloy) with Oxygen-containing Mediums // 
Proceedings of IAEA Technical Committee on Behaviour of LWR Core Materials under Accident Conditions, held in Dimitrovgrad, Russia, on 9-13 October, 1995. IAEA-TECDOC-921, Vienna, 1996, p. 117-128.

6. V.Yu. Tonkov, A.M. Kaptel'tsev, I.V. Golikov, et al. Vliyaniye okisleniya $\mathrm{v}$ vodyanom pare na mekhanicheskiye svoystva splava $\mathrm{Zr} 1 \% \mathrm{Nb}$ v temperaturnom intervale $20-1000{ }^{\circ} \mathrm{C} / /$ Voprosy atomnoy nauki i tekhniki. Seriya "Materialovedeniye $i$ novyye materialy”. 1990, N 4 (38), p. 7-11 (in Russian).

7. Yu. Bibilashvily, N. Sokolov, L. AndreevaAndrievskaya, Yu. Vlasov, O. Nechaeva, A. Salatov. Assesment of WWER Fuel Condition in Design Basis
Accident // Proceedings of an International Seminar, held in St. Constantine, Varna, Bulgaria, on 7-11 November, 1994.

8. S. Kawasaki. A review of studies on behaviour of fuel cladding under under $\mathrm{LOCA}^{\mathrm{s}}$ // Proceedings of Japan-USSR seminar on LWR Fuels, held in Tokyo, Japan, 29-31 October, 1990.

9. H.M. Chang, A.M. Garde, T.F. Kassner. Development of oxygen embrittlement criterion for zircaloy cladding applicable to loss-of-coolant accident conditions in light-water reactors // Zirconium in the Nuclear Industry (Fourth Conference), ASTM STP 681, ASTM, 1979, p. 600-627.

Статья поступила в редакциюю 08.02.2021 2.

\title{
ИССЛЕДОВАНИЕ ПОВЕДЕНИЯ И СВОЙСТВ ОБОЛОЧЕК ТВЭЛОВ РЕАКТОРА ТИПА ВВЭР ИЗ СПЛАВА Zr1\% Nb В УСЛОВИЯХ АВАРИИ С ПОТЕРЕЙ ТЕПЛОНОСИТЕЛЯ
}

\author{
М.М. Семерак, С.С. Лыс
}

Приведены критерии безопасности, предъявляемые к состоянию твэлов в условиях проектных аварий с потерей теплоносителя для реакторных установок с ВВЭР. Представлен краткий обзор экспериментальных исследований, проведенных с целью обоснования критериев безопасности. Объем экспериментальных данных, полученных при исследовании поведения и свойств оболочек твэлов реактора типа ВВЭР из сплава $\mathrm{Zr} 1 \% \mathrm{Nb}$ в условиях нагружения, имитирующих стадию залива активной зоны водой при аварии с потерей теплоносителя, достаточен для суждения о характере и численном значении критериальных параметров охрупчивания с точки зрения стойкости оболочек при заливе и извлечении ТВС и транспортировке. Рассматриваются аварии с потерей теплоносителя первого контура, для которых характерно ухудшение условий теплоотвода от твэлов. В процессе аварий допустима разгерметизация оболочки твэла, однако при этом должны сохраняться возможности охлаждения твэла с измененной геометрией и разборки (выгрузки) активной зоны после аварии.

\section{ДОСЛІДЖЕННЯ ПОВЕДІНКИ І ВЛАСТИВОСТЕЙ ОБОЛОНОК ТВЕЛІВ РЕАКТОРА ТИПУ ВВЕР ЗІ СПЛАВУ Zr1\% Nb В УМОВАХ АВАРІЇ 3 ВТРАТОЮ ТЕПЛОНОСІЯ}

\author{
М.М. Семерак, С.С. Лис
}

Наведено критерії безпеки, що пред'являються до стану твелів в умовах проектних аварій 3 втратою теплоносія для реакторних установок 3 ВВЕР. Представлений короткий огляд експериментальних досліджень, проведених 3 метою обгрунтування критеріїв безпеки. Обсяг експериментальних даних, отриманих при дослідженні поведінки і властивостей оболонок твелів реактора типу ВВЕР зі сплаву $\mathrm{Zr} 1 \% \mathrm{Nb}$ в умовах навантаження, імітуючих стадію затоплення активної зони водою при аварії з втратою теплоносія, достатній для судження про характер і чисельне значення критеріальних параметрів окрихчування 3 точки зору стійкості оболонок під час заливу і видаленні ТВ3 та транспортуванні. Розглядаються аварії з втратою теплоносія першого контуру, для яких характерне погіршення умов тепловідведення від твелів. У процесі аварій допустима розгерметизація оболонки твела, однак при цьому повинна зберігатися можливість охолодження твела зі зміненою геометрією і можливість розбирання (вивантаження) активної зони після аварії. 